\title{
Broken wholeness: A critical analysis of Henri JM Nouwen's spirituality of vulnerability and its possible value for the current discourse on health and wholeness.
}

\author{
Van der Merwe, Riaan \\ Stellenbosch University \\ riaanvdm7@gmail.com
}

\begin{abstract}
This essay investigates whether the counter-cultural spiritual formation theology of Henri Nouwen could make a significant contribution to the current discourse on an inclusive, gender-equitable, spirituality-based approach to holistic health. Three main relationships feature in the majority of Nouwen's works: the relationship to self, the relationship to others and the relationship to God. This foundational framework of Nouwen is used to structure this inquiry into the possible enduring value of certain core concepts that Nouwen developed within his triad of 'movements' toward wholeness. In his thinking about the movement of Reaching Out to our Fellow Human Beings, the concept of Vulnerability emerges as a key component of his theology and it will be the focus of this article. In a second article the value of Nouwen's seminal thinking on Embodiment (the movement of Reaching Out to our Innermost Self) and in a third his lifelong engagement with Mystery (the movement of Reaching Out to our God) will also be brought into discussion with current thinking.
\end{abstract}

Key words

Vulnerability; health; wholeness; spirituality; Henri JM Nouwen

\section{Introduction: The emerging intellectual paradigm shift in the discourse on healing and wholeness}

Henri J. M. Nouwen was a theological artist. Artists have the uncanny knack of being ahead of their time in discerning (and shaping) a way of looking at the world that is just emerging in their own time. Laurent Nouwen, Henri Nouwen's youngest brother and currently the director of 
the Dutch Henri Nouwen Stichting in Rotterdam, admits that he had not fully comprehended the extent and significance of his brother's work and artistry until after his death. Since then he has come to see him as a very special kind of artist, almost like Vincent van Gogh, whose true talent was only discovered after his death.

Henri was a little like Vincent van Gogh in the way that he taught us to look differently. After Van Gogh we looked at the world differently. Henri is also a person who gave us a different view. We can look with his eyes as well. He provides us with an alternative way of looking at reality. We can describe Henri as a theological artist. And sometimes an artist is ahead of his time. I am most interested in why he is still read so widely. Therefore I am more interested in the reader than in the author. What is the reader looking for today? Why is there such a positive response to his simple writings? ${ }^{1}$

Part of the reason for Nouwen's continuing popularity today might be that, as a true artist, he discerned in his time certain core ideas that would inform the theological discourse for the foreseeable future. This article hopes to investigate the current relevance of one of the rich spiritual veins that Henri Nouwen tapped into that is increasingly emerging as part of a new way of thinking about health and wholeness. Henri Nouwen's sensitive and honest theological and existential journey into 'vulnerability' could possibly add value and deepen the level of the current discourse on what wholeness (and holiness) comprises.

In the current discourse on global health care there seems to be a strong movement towards recognizing and including the essential role of religion and spirituality. In an important contribution Christoph Benn, on behalf of the Global Fund to Fight Aids, TB and Malaria, speaks about 'The Continued Paradigm Shift in Global Health and the Role of the Faith Community' (Benn 2011:10). In an equally significant contribution, Gillian Paterson, Research Fellow at Heythrop College, University of London, presents us with a persuasive argument for this inclusion in "Discovering Fire: Changes in International Thinking on Health Care - The Challenges

1 Laurent Nouwen. Recorded personal interview, Henri Nouwen Stichting, Rotterdam, June 19, 2014. (The recording is in the possession of the author). 
for Religion" (Paterson 2011:16). A number of researchers in the fields of theology, psychology, medicine and whole-person caring present convincing arguments concerning the vital importance of integrated bodymind-spirit healing in a whole-systems approach. ${ }^{2}$

From an African perspective James Cochrane, one of the three co-principals of the African Religious Health Assets Program, is very positive about the shift in theory formation that is slowly taking place away from "utilitarian, or market-based, or rational choice theories of the human good, all of which are anthropologically superficial and relevant only within strict limits". $\mathrm{He}$ discerns a movement towards a slowly developing new kind of intellectual paradigm and formulates his position as follows:

...signs of a paradigm shift are now everywhere, partly impelled by the failures of current models, and partly by the collapse of the radical secularization thesis that dominated most of the scientific community, across disciplines, through the latter half of the $20^{\text {th }}$ century. In the new paradigm that is emerging, we will recognize that every aspect of applied health sciences has a dynamic link to religious health worlds and religious assets, and that every aspect of religious phenomena has a health relevance and health implication (Cochrane, Schmid \& Cutts 2006:72).

Cochrane pointedly gives the following illustration of the typical African way of thinking about health and religion: "In Sesotho for example, as in isiXhosa, Bemba and other related African languages, there are no direct equivalents for either 'religion' or 'health', at least not if they are understood separately from each other. The only appropriate Sesotho word is bophelo (imphilo in isiXhosa, ubumi in Bemba). This word combines both our sense of what religion is and what health is, and also extends to include not just

2 See for example Pete Scazzero's Emotionally Healthy Spirituality (Scazzero 2006:39) and Dr. Paul Brand in the influential book Transforming Health: Christian approaches to Healing and Wholeness. Writing about "The laws of health and wholeness" the physician explains: "We are all trained in our own narrow specialization, and get used to thinking in terms of the laws that govern the aspects of health and healing that are responsive to those laws. If we are Christian physicians, we need to accept disciplines of thought which take into account the basic laws of wholeness of body, mind and spirit together" (Brand 1995:40). 
the individual body, but also the social body from which the individual's health is inseparable" (Cochrane, Schmid \& Cutts 2006: 68,69).

It is clear that this wider frame of reference and more inclusive point of departure for thinking about health matters offers new momentum for broadening the understanding of the concept of what holistic health comprises, and ways in which healing can be nurtured, promoted and maintained. "Healing" takes on a whole new meaning if the very definition of what health entails is changing. The inclusion of the religious dimension as an important factor in thinking about health enriches the whole area of health research and praxis in profound ways. Among other things, it means that certain aspects of religion and spirituality need to be carefully explored and weighed to determine in which ways they could possibly add value to the current discourse on health and wholeness.

The innovative, counter-cultural spiritual formation theory of Henri J.M. Nouwen could present such fertile ground from which fresh perspectives and new dimensions of praxis might arise in fields such as health, theology, development, gender, and integral well-being. The gradual worldwide philosophical "paradigm shift" away from an exclusively modernist scientific approach asks for a different kind of spiritual and theological approach to issues of private and public health. Without discounting the important contributions gained from the modernist world of "scientific" calculations and measurements, and without uncritically adopting "postmodernism" as philosophical frame of reference ${ }^{3}$, one could argue that the more "non-dualistic" approach of someone like Henri Nouwen provides an important alternative theological approach to life, health and well-being.

A brief survey of recent literature and current opinions about Henri Nouwen's life and writings reveals that his legacy is still widely judged to be extraordinarily relevant for the current theological discourse. Richard Rohr, in his foreword to Wil Hernandez's third book in a trilogy on the legacy of Henri Nouwen, affirms that Nouwen's life, spirituality and theology have enduring relevance for us today as "an excellent seer, inviting us into the same seeing" (Hernandez 2012: Kindle location 106).

3 Prof. D.J. Smit pointedly refers to "so-called" postmodernism, since he is not convinced that the term is very helpful in the South African context to help us discern the real challenges that confront us. (Smit 2000:23). 
He concurs with Hernandez's framing of Nouwen's thought in terms of his natural ability to be a nondualistic thinker, and his ability to hold wouldbe tensions in a very creative balance At the end of his third book on Nouwen, Hernandez summarises the value of Nouwen's way of thinking in the movement towards wholeness and integration as follows: "Henri Nouwen saw things differently and operated out of a different framework of thinking because he personified the non-dualistic consciousness characteristic of the contemplative mystics" (Hernandez 2012: Kindle Location 2006). In the opinion of Michael Higgins and Kevin Burns, who in 2012 constructed a radio series and published a book on the life and legacy of Nouwen under the title Genius Born of Anguish, the fact that Nouwen represented "the quintessential post-modern quester" accounts for much of his continuing relevance today (Higgens \& Burns 2012: Kindle location 117). Michael Ford, another researcher into the life and enduring legacy of Henri Nouwen, also describes the surprising continuing global impact of this Wounded Prophet: "In the time since Nouwen's death, there has been an upsurge of interest in his books, which are selling around the world in greater numbers than ever before. The Henri Nouwen Literary Centre, set up in his memory at Daybreak, deals daily with inquiries from people in many different countries and is clearly witnessing the fruits of his lifelong endeavours. Henri Nouwen Societies have been formed in North America and Holland, while retreats and conferences are doing much to evaluate his work and legacy" (Ford 1999: 208). In a recent reconstruction and publication of Henri Nouwen's unpublished class notes and other writings on spiritual formation, we are presented with a fresh and creative approach to formation for whole-person health. The lasting value of Nouwen's approach is described as follows: "The fruit of Nouwen's creative and integrative work in the field of pastoral psychology is a new, transformative, non-systematic approach to spiritual formation". Some interpreters have called Nouwen's approach a "spirituality of imperfection" (Nouwen, Christensen \& Laird 2010: Kindle Location 2147).

In the previously mentioned personal interview with Laurent Nouwen, the younger brother of Henri Nouwen, he responded to this researcher's question about the contemporary relevance and popularity of his brother Henri Nouwen's work in the following way: 
I am quite amazed by it. I cannot really say about the rest of the world, but I have a good picture of sales of his books in Holland and Germany, because I represent the estate. What I see is that book sales are still today more or less on an equal level. Even last Sunday there was a Protestant TV show about Henri, 18 years after his death. They repeat it every year. I was also interviewed on the program by Bobby Schuller. There is still this amazing interest across all denominations. I am very amazed. So it must touch a deeper cry. ${ }^{4}$

Obviously Henri Nouwen still speaks the language of many people looking for integral wholeness, not just in America or Europe, but worldwide. This article hopes to make a contribution to his lasting legacy by responding to the challenge of theologically analysing one of the crucial aspects in the current discourse on holistic health, viz. the role of spirituality and, specifically, vulnerability. As the most widely read author in the field of Christian spirituality at the time of his death in 1996 (Beumer 1997:13) and still one of the most influential voices in the field of spirituality and theology in recent times ${ }^{5}$ Henri JM Nouwen embodied a spirituality of compassionate vulnerability that touched and healed the lives of millions worldwide.

Therefore, thorough analysis and critical evaluation of core aspects of Henri Nouwen's thinking about healing and wholeness seems indicated. However, if this is merely to be attempted from a modernistic epistemological framework of so-called "objective science" we would do the legacy of Henri Nouwen grave injustice. His approach to spirituality and spiritual formation does not involve minute distinctions and the construction of rigid schemes. Henri Nouwen's caustic observation in this regard was:

Many great saints have described their religious experiences, and many lesser saints have systematized them into different phases,

4 Laurent Nouwen, June 19, 2014. Recorded personal interview, Henri Nouwen Stichting, Rotterdam. (Recording in possession of author.)

5 Hillary Clinton, when recently asked by Oprah Winfrey about the most significant books in her life, replied: "There's simply no way to take a lifetime of reading great books and single out a handful as the most influential in my life. So I've picked one The Return of the Prodigal Son: A Story of Homecoming - by Henri Nouwen, which had a profound effect on me and that I believe will be equally meaningful to others." (Oprah Winfrey Show, May 2014) 
levels or stages. These distinctions can be helpful for those who write books and for those who use them to instruct, but it is of great importance that we leave the world of measurements behind when we speak about the life of the spirit (Nouwen 1987: 18).

Nouwen chooses not to speak about steps or stages on the way to perfection. He prefers using the dynamic metaphor of movements towards full, mature humanity. In their recent reconstruction of the class notes of Nouwen's formerly unpublished course on spiritual formation when he was a professor at Yale, two of his former students recorded Nouwen's own words on this matter:

Spiritual formation, I have come to believe, is not about steps or stages on the way to perfection. It's about the movements from the mind to the heart through prayer in its many forms that reunites us with God, each other, and our truest selves (Nouwen, Christenson \& Laird 2013: Kindle Location 139). ${ }^{6}$

The academic surmise upon which this investigation is undertaken is that the spiritual "movements" towards wholeness that Henri Nouwen identified might hold promise for the current discourse on growth, healing and holistic health. The structure of this paper is an attempt to honour Nouwen's way of doing theology. From amongst the various movements colourfully described by Nouwen in a number of his books, this study identifies three as representative of his spiritual formation theory and which may be significant for today's circumstances. ${ }^{7}$ They have been synthesized from various sources and renamed for the current context in a style that Henri Nouwen might possibly have employed today. In broad terms the study is constructed to reflect a pattern that Nouwen makes use of in many

6 Nouwen returns to this image of a movement "from the head to the heart" in many of his books. Referring to the mystic Theophan the Recluse, he sees prayer as "standing in the presence of God with the mind in the heart - that is, in the point of our being where there are no divisions or distinctions and where we are totally one within ourselves, with God, and with others and the whole of creation" (Nouwen, Christiansen \& Laird 2013: Kindle Location 149).

7 Jurjen Beumer, a close Dutch friend of Henri Nouwen, also sees the three movements described by Nouwen in Reaching Out (Open Uw Hart) as representative of the core of his theology: "Er komen in dit boek een aantal lijnen van zijn denken, voelen en ervaren bij elkaar", in Onrustig zoeken naar God: de spiritualiteit van Henri Nouwen, (Beumer 1997:40). 
of his books, in describing the "outward" movement to find God in others, the "inward" movement to find God our deepest being, and the journey "upward" or "beyond" to find God in all things. This article investigates the implications of the first of these: the outward movement toward vulnerability. Embodiment and mysticism, representing the "inward" and "upward" movements will be considered in further articles.

\section{The way of vulnerability: From hostility to hospitality.}

\subsection{Nouwen's theology of weakness}

At a recent seminar on Vulnerability, Churches and HIV, convened by the Church of Sweden's Research Department, Henri Nouwen's concept of compassion as vulnerability was used by the keynote speaker, professor Musa W Dube of Botswana University, to illustrate that the "way of vulnerability" is a vital component of the type of theology the church needs to be able to face the health challenges with which she is confronted today She quotes the following iconic words of Henri Nouwen as vital for today's thinking on health and healing:

Compassion requires us to be weak with the weak, vulnerable with the vulnerable, and powerless with the powerless. Compassion means full immersion in the condition of being human (Dube, in Gunner (ed) 2009:12).

The "way of vulnerability" that Nouwen embodied and opened up for many through his writings seems to gain in significance with the passing years after his death. Nouwen's name came to be associated with the phrase "The Wounded Healer" ever since the publication of his foundational book with that title in 1979. Nouwen's life story, literary legacy and theological contribution is very aptly summed up in this phrase. In his inimitable way Nouwen popularised "The Wounded Healer" as a metaphor for ministers who are called not only to care for other people's wounds but to make their own wounds into an important source of healing. He explains the deeper meaning of this phrase as follows:

Making one's own wounds a source of healing, therefore, does not call for a sharing of superficial personal pains but for a constant willingness to see one's own pain as rising from the depth of the human condition which all men (sic) share (Nouwen 1979: 88). 
Only by facing and embracing our woundedness and weakness and moving away from the illusion of being able to control life through gaining more and more power can we discover the healing potential of the way of vulnerability. According to Nouwen, a "Theology of Weakness" is necessary to counter the lust for power that has entrapped and corrupted the human spirit in the western world. The response of God to this "diabolic power" was to choose powerlessness. God chose to enter human history in complete weakness, as a vulnerable, dependent human baby. In Jesus of Nazareth the powerless God appeared among us to unmask our illusion of power. The movement from abusive power to power through powerlessness is what we are called to. A theology of weakness is a theology of divine empowering, not a theology for weaklings. It is movement from the illusion of being in control to complete surrender to the power of God. The all-pervading conviction in western society is that power is a good thing. But more power, in the form of money, connections, fame, intellectual ability, skills, is only a way to get some sense of security and control and strengthen the illusion that life is ours to dispose of.

Nouwen develops the Judeo-Christian concept of hospitality ${ }^{8}$ as a healing ministry, because it takes away the illusion that wholeness can simply be given by one person to another. The pain and loneliness is not taken away, but when the host feels at home in his or her own house they can "create a free and fearless space" for others where they can recognize their pain on a level where it can be shared. Shared pain is no longer paralyzing but mobilizing. A true healing ministry helps to clear away the false supposition that there should be no fear or loneliness, no confusion or doubt. These sufferings can only be dealt with creatively when they are understood as wounds integral to our human condition. The wounds and pains are not necessarily cured or alleviated, but they become openings or occasions for a new vision.

In order to be a hospitable host, we need to embrace poverty. Nouwen advocates a "poverty of mind" and a "poverty of heart". In order for us to be able to really listen, to be open to discover the gift of the other,

8 The Greek word the New Testament used for hospitality is philoxenia. It refers to love for the stranger. It is the exact opposite of xenophobia, fear or hate of the stranger. See Vosloo RR: Body and Health in the light of the theology of Dietrich Bonhoeffer, in Religion and Theology, 2006:15. 
we need a spiritual attitude of growing willingness to recognize the incomprehensibility of the mystery of life. We need a docta ignorantia, a learned ignorance, an articulate not-knowing, so that we can mature in giving up our illusion of control in order to be controlled by God. Poverty of mind makes one able to receive the word from others and the Other with great attention.

The more mature we become, the more we will become able to give up our inclination to grasp, catch and comprehend the fullness of life and the more we will be ready to let life enter into us (Nouwen 1975: 96).

God is not only greater than our mind, he is also greater than our heart. So a "poverty of the heart" is also necessary for us to be a good host and make room for the stranger. Just as we have to avoid the temptation to adapt God to our small concepts we have to avoid adapting God to our small feelings.

An inflated heart can make us very intolerant. But when we are willing to detach ourselves from making our own limited experience the criterion for our approach to others, we may be able to see that life is greater than our life, history is greater than our history, experience greater than our experience, God greater than our God (Nouwen 1975:98).

Nouwen appeals to what he regards as the core of the Christian message: God's self-revelation in the kenosis of Jesus Christ (Phil 2:6-8). God does not reveal Godself as the powerful other, unapproachable in omniscience, omnipotence and omnipresence, but God is revealed in the incarnation. He came to us in the vulnerable way of Jesus Christ. Nouwen argues that God thereby also reveals to us the movement of our spiritual life. It is not a movement from weakness to power, but a movement in which we become less and less defensive and ever more open and vulnerable. Part of the mystique that still surrounds the legacy of Henri Nouwen is that he not only lucidly wrote about this "downward" movement throughout his career, but that his own life story dramatically illustrates the agony and ecstasy of embarking on this "Way of Vulnerability".

A brief exploration of the current discourse on vulnerability could reveal fertile links to the theology of Nouwen. 


\subsection{The fragile discourse on vulnerability}

One of the major influences on Henri Nouwen's thinking and the course of his life story was Jean Vanier, founder of L'Arche, the international network of communities where "core members", people with intellectual and other disabilities, and "assistants", people without intellectual disabilities, share life together as fellow human beings. Vanier initially, and unexpectedly, invited Nouwen to spend some time with him, his mother and the L'Arche community at Trosly in France at a time when Nouwen needed to make major decisions and life changes. This eventually led to Nouwen's move from being a prestigious professor at universities like Yale and Harvard to spending the last ten years of his life as assistant and pastor to the disabled at the Daybreak L'Arche community in Toronto, Canada. Vanier and Nouwen became good friends and continued to be friends until Nouwen's death in 1996. Vanier delivered a moving eulogy at Henri Nouwen's funeral. Jean Vanier, along with the respected theologian Stanley Hauerwas, ${ }^{9}$ represent leading voices in the current discourse on vulnerability, disability and the Christian tradition.

In the defining book that Vanier and Hauerwas co-authored in 2008, Living Gently in a Violent World: The Prophetic Witness of Weakness, both the authors take as their point of departure the fundamental gospel principle that the weakest and least presentable people are indispensable to the church (1 Cor 12:22). For the major paradigm shift that is implied in really taking this principle seriously, the L'Arche communities provide a much needed exemplar.

Henri Nouwen was attracted to the L'Arche ideal and was eventually convinced that this represented the type of "home" where he wanted to spend the last years of his life: not in the power-hungry, success-driven academic world where the bottom line is always achievement and competition, but in the gentle world of mutual trust and caring of L'Arche. Working as physical assistant and pastor for the Daybreak L'Arche community in Toronto, Canada, Nouwen introduced to his huge readership the L'Arche concept of the importance of the so-called handicapped and marginalized members of society.

9 Named as America’s “best theologian” by Time Magazine in 2001. 
The L'Arche communities with their ethos of "living with" rather than "doing for", provide a unique model of profound inclusive spirituality. Jean Vanier in his gentle but convincing way explains the mystery of God's choice for the people at the bottom of society, "to shame the clever and the powerful" (1 Cor 1:18-31).

The mystery of people with disabilities is that they long for authentic and loving relationships more than for power. They are not obsessed with being well-situated in a group that offers acclaim and promotion. They are crying for what matters most: love. And God hears their cry because in some way they respond to the cry of God, which is to give love (Hauerwas \& Vanier 2008: 30).

Stanley Hauerwas, speaking on “The Politics of Gentleness", uses Vanier's example and embodiment of vulnerability and gentleness at L'Arche to develop a fiery critique of contemporary assumptions about wholeness, ethics and politics. ${ }^{10}$ His main point of criticism is that liberal political theory per definition excludes people with mental disabilities. He refers to Hans Reinders to explain that liberal political theory is based on the assumption that individual persons are free to live their own lives as they prefer, provided that they allow other people equal freedom to do the same. "Persons", according to liberal democracy, are constituted by the powers of reason and free will. Only persons, in the sense of rational moral agents, can receive equal concern and respect, which causes a problem with respect to the inclusion of severely handicapped people. Approaching the area of disability along the way of vulnerability might help us to adopt a proper mode of humility when trying to unravel aspects of inscrutable mystery. We would do well to keep in mind that we are engaging with one aspect of the matter, which does not enable us to grasp the whole.

10 The toughness of Hauerwas and the gentleness of Vanier creates an interesting synergy. Hauerwas is aware of a possible rhetorical problem: "My style is polemical and many, I suspect, would not characterize my work as gentle or tender. Accordingly I worry that my attempt to argue for the significance of gentleness for Jean and L'Arche may betray what he and L'Arche are about. My only defence is that God has given us different tasks. My task has been to put Vanier's wisdom into conversation with philosophical and political positions that I fear are antithetical - if not outright threats - to the people we call 'intellectually disabled'. That means however that my writing style has been aggressive and confrontational (Hauerwas \& Vanier 2008: 78-79). 
In the evolving academic field of theological disability studies ${ }^{11}$ there is a growing consensus about the necessity of changing the conversation on "disability" and "normalcy" away from a binary "us-them" way of thinking, especially as couched in terms of "normal" versus "abnormal". Thomas Reynolds sees two major changes that need to happen in this discourse. The first is that we should shift away from seeing disability as a "tragic flaw". The social construct of "normality", which creates the difference between bodies that are "able" and those that are "disabled", should be challenged. The second is that there is a need to move away from representing disability merely as a problem to be included according to the good graces of a community.

If we grant that "normal" is a standard that is socially constructed, we are brought to recognise that it can also be critiqued and deconstructed. The basis for this, I believe, lies in something all human beings share, which undercuts the "us-them" binary: vulnerability (Reinders, in Claassens, Schwartz \& Hansen (Eds) 2013: 20).

Another influential voice concerning vulnerability and dependence is that of the philosopher Alisdair MacIntyre. In his Dependent Rational Animals: Why Human Beings Need the Virtues, MacIntire makes a strong case for "the virtues of acknowledged dependence". (MacIntire 1999:119). His argument is that human beings must be understood first as animals, but then as a special sort of animal. He discusses in detail those aspects of our nature that are shared with other intelligent species such as dolphins, particularly the dependence and vulnerability that mark every period of our life. According to MacIntyre, disability should be taken seriously as a natural fact of life from which no one is exempt. There is a scale of disability on which we all find ourselves in different periods of our life. In order to "flourish" and to protect themselves from many dangers, dolphins need each other. In order for human beings to "flourish" like dolphins, but then as independent, reasoning animals, we need certain "virtues" which we cannot acquire without the sustained help of others on whom we depend, especially, but

11 "Over the past few decades there has been a growing interest in the relation between theology and disability in the academic literature that suggests we are witnessing the birth of a new field" (Reinders 2013: 31). 
not exclusively, our parents. We will need not only the virtues that help us grow toward independence (such as risk-taking, patience, courage and temperateness), but also the virtues of "acknowledged dependence" (such as gratitude, courtesy, and forbearance). MacIntyre asserts that human life is a life of reciprocal indebtedness. Political community exists not only to adjust competing interests or to provide goods and services (as in liberal democracy theory). It exists to make possible the kind of community in which joint deliberation about life can take place within the framework of reciprocal indebtedness and just generosity.

Thomas Reynolds, in his overview of the current discourse on disability and vulnerability, quotes Jean Vanier, Stanley Hauerwas, Michel Foucault, Jurgen Moltmann and Nancy Eiesland in support of his conviction that in the end there is no hard and fast line between ability and disability and that every life has its limitations, vulnerabilities and weaknesses.

Thus I contend that disability is both anthropologically and redemptively fundamental. It signifies vulnerability as a condition of the gift of sharing life with one another. Yet there is a need for healing, not because disability signifies "bodies gone wrong", but because it entails real suffering, sometimes bodily, and in many cases communal in the form of alienation, exclusion and assimilation. (Reynolds, in Claassens, Schwartz \& Hansen (Eds), 2013: 20).

In her insightful analysis of the biblical story of Job, Juliana Claassens concludes with Reynolds that all humans are "only partially and temporarily able-bodied" (Claassens, in Claassens, Swartz \& Hansen (eds.) 2013: 64). Only when we realize our own vulnerability and accept various degrees of disability as part of life will we be able to grant true hospitality to those who are equally vulnerable.

In his inimitable way Henri Nouwen, years ago, opened up this new kind of thinking about what health comprises, suggesting a new paradigm from which to consider what wholeness is, which will continue to influence the discourse on healing for many years to come:

A Christian community is therefore a healing community not because wounds are cured and pains are relieved, but because 
wounds and pains become openings or occasions for a new vision. Mutual confession then becomes a mutual deepening of hope, and sharing weakness becomes a reminder to one and all of the coming strength (Nouwen 1994: 94).

Nouwen referred to himself as a "hyphenated priest": a psychologist-priest. Yolanda Dreyer investigated the underlying epistemology of Nouwen's theological model to ascertain whether he was working primarily from a psychological or a theological frame of reference. This is important because of the distinctive epistemologies underlying the psychological and theological discourses. Referring to the strong influence that Heidegger had on Nouwen's thinking she observes that Nouwen's spirituality incorporates, but then goes beyond, the epistemology of psychology. Since much of psychology today is still essentialist, empiricist and positivist, Nouwen opened a way of moving beyond an empiricist epistemology "that assumes the accumulation of knowledge is only gained by information gathered via the techniques and methods of the senses: objectified and empirical data" (Dreyer 2003:715-733).

Henri Nouwen's movement away from the modernist values of being an individualist, an upwardly mobile achiever at Ivy League universities, to becoming a dependent, downwardly mobile servant, at home with the mentally wounded at L'Arche, will continue to challenge prevailing attitudes and practices concerning health and wholeness for a long time. In a posthumous publication of the content of a workshop that was recorded near the end of his life, Nouwen made it clear that he considered following the fragile way of vulnerability, "choosing the way of Jesus", as the way to a different, broken, but beautiful kind of wholeness:

This way takes us on a path through the desert of suffering to our hidden wholeness and to our utter beauty in the eyes of the One we name God (Nouwen 2009:111).

In a foreword that Henri Nouwen wrote for a pamphlet that Parker J. Palmer composed as a "celebration of the contradictions in Thomas Merton's thought"12 we can sense Nouwen's joy in the hidden, paradoxical,

12 In the Belly of a Paradox: a Celebration of Contradiction in the Thought of Thomas Merton. Palmer, 1979. 
broken but beautiful wholeness that he sees reflected in the lives of people like Thomas Merton and Parker Palmer. "This essay is short, fresh, and obviously written with a twinkle in the eye. And the greatest surprise of all is that it not only leads us closer to the spirit of Merton, but closer to Him in whose service Merton juggled contradiction and paradox. It is a reason for joy to see these two kindred spirits together!" (Nouwen, in Palmer 2004: 2)

This joy exponentially expands in encountering the beauty of "broken wholeness/holiness" in other "kindred spirits" like St. Paul/Saul, Vincent van Gogh, Henri J.M. Nouwen... and Jesus Christ. In the words of Parker Palmer: "Wholeness does not mean perfection: it means embracing brokenness as an integral part of life. Knowing this gives me hope that human wholeness - mine, yours, ours - need not be a utopian dream, if we can use devastation as a seedbed for new life" (Palmer 2004: 5).

Sue Mosteller, a close friend and colleague of Henri Nouwen at Daybreak L'Arche, and presently the literary executrix of Henry Nouwen's estate, wrote a poignant book some time after his death, which she entitled Light Through the Crack: Life after Loss. The title refers to a song by Leonard Cohen which manages to express in music and poetry something of the lasting legacy of a theological artist and wounded healer like Henri JM Nouwen:

Ring the bells that still can ring,

Forget your perfect offering.

There is a crack in everything,

That's how the light gets in.

(Mosteller 2006)

\section{Bibliography}

Benn, C 2009. On Being an HIV-positive Church and Doing Theology in an HIV-positive World, in Gunner, G (Ed). Vulnerability, Churches and HIV. Eugene Oregon: Pickwick Publications. 12-15.

Beumer, J 1997 Onrustig zoeken naar God: de spiritualiteit van Henri Nouwen. Tielt: Lannoo. 
Brand, P 1995. In Ram, E. (ed), Transforming Health: Christian approaches to Healing and Wholeness. Monrovia, CA: MARC Publications.

Claassens, J 2013. Job, theology and disability: moving towards a new kind of speech, in Claassens, Swartz \& Hansen, (eds). Searching for Dignity: Conversations on Human Dignity, Theology and Disability: 64

Cochrane, JR, Schmid, B, Cutts, T 2006. When religion and health align: Mobilising religious health assets for transformation. Pietermaritzburg: Cluster Publications.

Edwards, C 1989. Van Gogh and God: A creative spiritual quest. Chicago: Loyola University Press.

Gunner, G 2009 (Ed) Vulnerability, Churches and HIV. Research Series no 1:16-19. Eugene Oregon: Pickwick Publications.

Hauerwas, S \& Vanier, J 2008. Living gently in a violent world; the prophetic witness of weakness. Downers Grove, Illinois: IVP Books.

Hernandez, J 2012. Henri Nouwen and spiritual polarities: A life of tension. New York: Paulist Press.

Higgins, M \& Burns, K 2012. Genius Born of Anguish, New York: Paulist Press.

MacIntire M 1999. Dependent rational animals: Why human beings need the virtues. Chicago and La Salle: Open Court.

Mosteller, S 2006. Light through the crack: Life after loss. New York: Doubleday.

Nouwen HJM 1972. The wounded healer: Ministry in contemporary society. New York: Doubleday.

Nouwen HJM 1975. Reaching out: The three movements of the spiritual life. New York: Doubleday.

Nouwen, HJM 1987 Behold the beauty of the Lord: Praying with icons. Notre Dame Indiana: Ave Maria Press.

Nouwen, HJM 2009. Home Tonight: Further Reflections on the Parable of the Prodigal Son. London: Darton, Longman \& Todd. 
Nouwen, HJM 2010, with MJ Christensen \& RJ Laird. Spiritual Formation: Following the Movements of the Spirit. New York: Harper Collins.

Nouwen, HJM Christenson \& Laird, 2013. Discernment: Reading the signs of daily life. New York: Harper Collins.

Palmer, PJ 2004. A hidden wholeness: The journey toward an undivided life. San Francisco: Jossey Bass.

Palmer, PJ 1979. In the belly of a paradox: A celebration of contradictions in the thought of Thomas Merton. Wallingford, PA: Pendle Hill Publications.

Paterson, G 2009. Discovering Fire: Changes in International Thinking on Health Care - The Challenges for Religion, in Gunner, G (Ed). Vulnerability, Churches and HIV. Eugene Oregon: Pickwick Publications. 16-19

Reinders, H 2013, Theology and Disability: What is the Question? In Claassens, Schwartz \& Hansen (Eds) Searching for Dignity: Conversations on Human Dignity, Theology and Disability, Stellenbosch: Sun Media.

Scazzero, P 2006. Emotionally Healthy Spirituality. Nashville Tennessee: Thomas Nelson.

Smit, DJ 2000. In diens van die tale Kanaäns: oor sistematiese teologie vandag Inaugural Lecture, University of Stellenbosch.

Vosloo, RR 2006. Body and Health in the light of the theology of Dietrich Bonhoeffer. Religion and Theology, 13 (1): 23 -37. 